\title{
Spatial and temporal variations of wave energy in the nearshore waters of the central west coast of India
}

\author{
M. M. Amrutha and V. Sanil Kumar \\ Ocean Engineering Division, Council of Scientific and Industrial Research - National Institute of Oceanography (CSIR-NIO), \\ Dona Paula, Goa, 403 004, India \\ Correspondence to: V. Sanil Kumar (sanil@ nio.org)
}

Received: 24 September 2016 - Revised: 18 November 2016 - Accepted: 28 November 2016 - Published: 16 December 2016

\begin{abstract}
Assessment of wave power potential at different water depths and time is required for identifying a wave power plant location. This study examines the variation in wave power off the central west coast of India at water depths of 30, 9 and $5 \mathrm{~m}$ based on waverider buoy measured wave data. The study shows a significant reduction $(\sim 10$ to $27 \%$ ) in wave power at $9 \mathrm{~m}$ water depth compared to $30 \mathrm{~m}$ and the wave power available at $5 \mathrm{~m}$ water depth is 20 to $23 \%$ less than that at $9 \mathrm{~m}$. At $9 \mathrm{~m}$ depth, the seasonal mean value of the wave power varied from $1.6 \mathrm{~kW} \mathrm{~m}^{-1}$ in the post-monsoon period (ONDJ) to $15.2 \mathrm{~kW} \mathrm{~m}^{-1}$ in the Indian summer monsoon (JJAS) period. During the Indian summer monsoon period, the variation of wave power in a day is up to $32 \mathrm{~kW} \mathrm{~m}^{-1}$. At $9 \mathrm{~m}$ water depth, the mean annual wave power is $6 \mathrm{~kW} \mathrm{~m}^{-1}$ and interannual variations up to $19.3 \%$ are observed during 2009-2014. High wave en$\operatorname{ergy}\left(>20 \mathrm{~kW} \mathrm{~m}^{-1}\right)$ at the study area is essentially from the directional sector $245-270^{\circ}$ and also $75 \%$ of the total annual wave energy is from this narrow directional sector, which is advantageous while aligning the wave energy converter.
\end{abstract}

Keywords. History of geophysics (ocean sciences) - meteorology and atmospheric dynamics (waves and tides)

\section{Introduction}

The generation of electricity and heat is responsible for $41 \%$ of the annual global carbon dioxide emissions from fuel combustion in 2011 (IEA, 2013). Replacing the present energy sources with renewable energy sources can reduce the global carbon dioxide emissions significantly. Ocean waves have the potential to become a commercially viable renewable energy source (Clement et al., 2002). Globally, wave energy resource assessments have been made for the Baltic Sea, the Black Sea, the Hawaiian islands, the North Sea, the Persian Gulf and for the seas around Australia, Brazil, Canada, California, Canary Islands, China, India, Iran, Ireland, Malaysia, Portugal, Taiwan, the United Kingdom and the United States (Barstow et al., 2008; Defne et al., 2009; Stopa et al., 2011; Saket and Etemad-Shahidi, 2012; Kamranzad et al., 2013; Gonçalves et al., 2014; Soares et al., 2014; Appendini et al., 2015; Contestabile et al., 2015; Rusu, 2015; Sanil Kumar and Anoop, 2015; Gallagher et al., 2016). Most of the studies on the assessment of wave power are carried out either through the wave data obtained from numerical model or reanalysis data; ERA-40 or ERA-Interim (Dee et al., 2011) of the European Centre for Medium-Range Weather Forecasts (ECMWF). The intercomparisons of measured energy period with ERA-Interim mean wave period suggest that the data of the latter show an encouraging agreement with the energy period (Contestabile et al., 2015). Sanil Kumar and Anoop (2015) compared the significant wave height based on ERA-Interim and that estimated from a waverider buoy from June to August in the northern Arabian Sea and reported that the mean error is within $5 \%$. A $10 \%$ error in the estimate of surface wind speed can lead to a 10-20\% error in significant wave height $\left(H_{\mathrm{S}}\right)$ and a $20-50 \%$ error in wave energy (Cavaleri, 1994). Hence, it is important to know how the estimate of wave energy based on the reanalysis data differ from that obtained from measured data over an annual cycle.

India has a long coastline of $5423 \mathrm{~km}$ along the mainland, annually receives around 5.7 million waves and has large wave energy resources (Sanil Kumar and Anoop, 2015). Along the coastal waters of India, the Indian Institute of Technology Madras in Chennai has conducted early studies on wave energy resources and wave energy conversion 
devices (Ravindran and Koola, 1991). In addition, a wave energy plant is located on the southwest coast of India at Vizhinjam, based on the nearshore oscillating water column (Ravindran and Koola, 1991; Mala et al., 2011). Based on the measured wave data covering a 1-year period, Sanil Kumar et al. (2013) reported temporal variations in nearshore wave power at four shallow water locations covering the east and west coasts of India. Recently, Sanil Kumar and Anoop (2015) examined the long-term variations in wave power at 19 deep water locations covering the Indian shelf seas based on ERA-Interim data.

Precise estimates of wave energy resources at close spatial and temporal resolution are required for planning and design of wave energy converters. The waves in the Arabian Sea show strong seasonal variation (Sanil Kumar and Anoop, 2015) with high waves during the Indian summer monsoon (June to September, hereafter referred as monsoon). The variability of the wave power in different time scales (monthly, seasonal and annual) needs to be known before finalizing a location for a wave power plant, since locations with steady wave power are preferred than locations with large seasonal and annual variations (Sanil Kumar and Anoop, 2015). Nowadays, most of the wave energy assessments are made in deep water to take advantage of the resource (which is larger) and most of the wave energy converters (WECs) are generally designed to be deployed at water depths greater than $25 \mathrm{~m}$ (e.g., the Wave Dragon; Kofoed et al., 2006) or even $50 \mathrm{~m}$ (e.g., the Pelamis; Henderson, 2006). A great challenge for wave power is the logistics of building a wave farm and connecting the cable to the mainland (Rusu, 2014). The capital investment is less if the wave power plant is closer to the coast. Hence, the deployment of WECs at shallower waters presents undoubtable advantages as lower mooring costs or cheaper and easier connection to the electrical network, which can compensate for a lower resource (as a consequence of energy dissipation due to bottom friction). In addition, some types of WECs (like oscillating water column; Falcao and Henriques, 2016) can operate in relatively shallow waters. Also in shallower water depths, the motion of water particles under a wave will be in horizontal ellipse, i.e., the horizontal back-and-forth surging motion is larger than the vertical up-and-down motion and at such locations different types of wave generation system can be planned than that used in deep water, where oscillatory motion is circular and diminishes exponentially with depth (URS, 2009), Therefore, the spatial variation of the wave resource along the nearshore area is a topic worthy of being investigated. No previous studies on the variation in wave power at different water depths across the shore based on measured wave data have been carried out in Indian waters. It is also essential to understand how the wave energy is distributed with respect to wave period and direction. Hence, the purpose of this research is to assess the change in wave energy from 30 to $9 \mathrm{~m}$ and from 9 to $5 \mathrm{~m}$ water depth and its temporal variations. The interannual variations in wave power at $9 \mathrm{~m}$

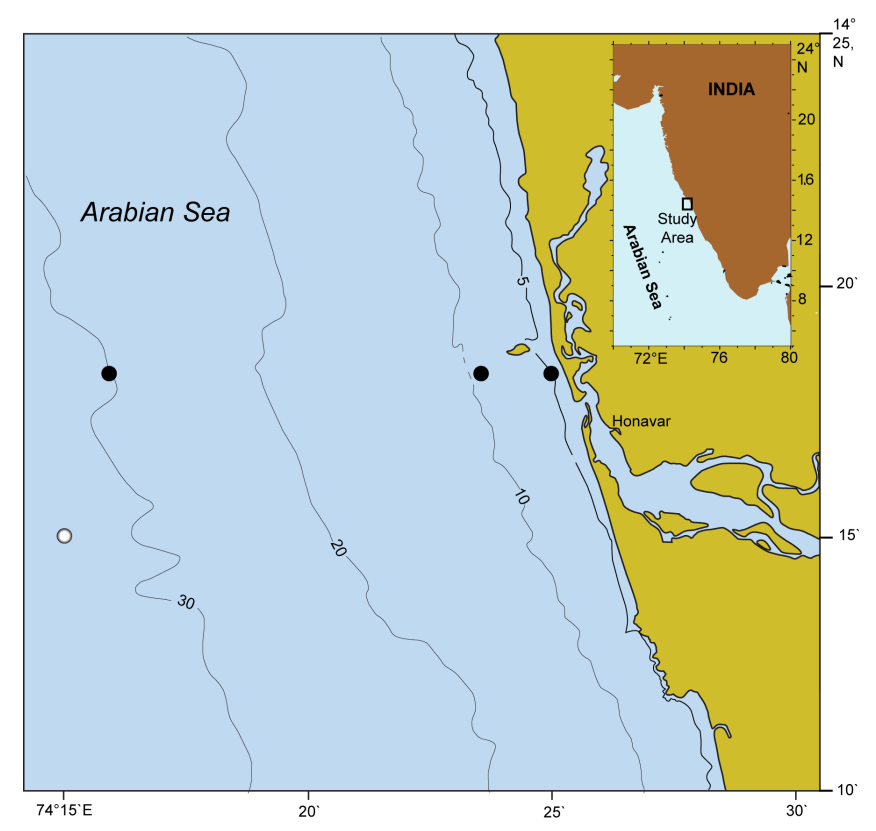

Figure 1. Map showing the study area. The black dots indicate the waverider buoy locations at 30,9 and $5 \mathrm{~m}$ water depths. The open circle indicate the ERA-I grid point.

water depth from 2009 to 2015 are also examined. The wave power estimated from ERA-Interim data is compared with that computed based on the measured wave data. The directional distribution of wave power is also required when selecting a wave power plant orientation and hence this aspect is also studied. The paper is organized as follows: Sect. 2 contains the data and methodology used in the study, Sect. 3 describes the results, Sect. 4 contains a discussion of the results and Sect. 5 summarizes the conclusions.

\section{Materials and methods}

\subsection{Wave data}

Measured wave data obtained from moored Datawell directional waverider buoys off Honavar (Fig. 1) are used in the study. The details of the measurements carried out at $5 \mathrm{~m}$ water depth $\left(14.304^{\circ} \mathrm{N}, 74.414^{\circ} \mathrm{E}\right), 9 \mathrm{~m}\left(14.304^{\circ} \mathrm{N}, 74.391^{\circ} \mathrm{E}\right)$ and $30 \mathrm{~m}$ water depth $\left(14.307^{\circ} \mathrm{N}, 74.291^{\circ} \mathrm{E}\right)$, and the length of data used in the study at each location are presented in Table 1 . The distance of the 5,9 and $30 \mathrm{~m}$ waverider buoy from the coast are $0.4,2.4$ and $16.4 \mathrm{~km}$, respectively, indicating that the measurement locations are within the territorial waters of the country. At $9 \mathrm{~m}$ water depth, the wave data were collected from 1 January 2009 to 31 December 2015. Due to interferences with local fishing boats, the buoy drifted from the moored location and hence continuous data could not be collected at $9 \mathrm{~m}$ water depth during July 2013. Also, in all years, the buoy and the moorings are retrieved and re- 
Table 1. Location and time period of data used in the study in different years.

\begin{tabular}{|c|c|c|c|c|c|c|c|c|c|}
\hline \multirow[t]{2}{*}{ Location } & \multirow[t]{2}{*}{ Period } & \multirow{2}{*}{$\begin{array}{r}\text { Number } \\
\text { of data }\end{array}$} & \multicolumn{2}{|c|}{$H_{\mathrm{S}}(\mathrm{m})$} & \multicolumn{2}{|c|}{$T_{z}(\mathrm{~s})$} & \multicolumn{2}{|c|}{$T_{\mathrm{e}}(\mathrm{s})$} & \multirow{2}{*}{$\begin{array}{r}\text { Wave } \\
\text { power } \\
\left(\mathrm{kW} \mathrm{m}^{-1}\right) \\
\text { Mean }\end{array}$} \\
\hline & & & Range & Mean & Range & Mean & Range & Mean & \\
\hline \multirow{7}{*}{$\begin{array}{l}9 \mathrm{~m} \text { water depth } \\
\left(14.304^{\circ} \mathrm{N},\right. \\
\left.74.391^{\circ} \mathrm{E}\right)\end{array}$} & 1 Jan-31 Dec 2009 & $\begin{array}{r}15921 \\
(90.9 \%)\end{array}$ & $0.21-4.37$ & 1.03 & $2.5-11.1$ & 5.6 & $4.1-14.6$ & 8.5 & 5.8 \\
\hline & 1 Jan-31 Dec 2010 & $\begin{array}{r}17459 \\
(99.7 \%)\end{array}$ & $0.22-3.70$ & 1.01 & $2.5-9.8$ & 5.5 & $4.1-15.0$ & 8.3 & 5.8 \\
\hline & 1 Jan-31 Dec 2011 & $\begin{array}{r}17421 \\
(99.4 \%)\end{array}$ & $0.26-3.82$ & 1.04 & $2.9-11.4$ & 5.7 & $4.1-15.8$ & 8.6 & 6.3 \\
\hline & 1 Jan-31 Dec 2012 & $\begin{array}{r}17524 \\
(99.7 \%)\end{array}$ & $0.29-3.41$ & 1.04 & $3.0-8.9$ & 5.5 & $4.4-14.1$ & 8.4 & 5.7 \\
\hline & $\begin{array}{l}1 \text { Jan-31 May and } \\
1 \text { Oct-31 Dec } 2013\end{array}$ & $\begin{array}{r}11596 \\
(66.2 \%)\end{array}$ & $0.26-1.80$ & 0.70 & $2.8-10.8$ & 5.1 & $4.3-16.0$ & 8.2 & 2.0 \\
\hline & 1 Jan-31 Dec 2014 & $\begin{array}{r}17429 \\
(99.5 \%)\end{array}$ & $0.23-4.09$ & 1.08 & $2.6-9.5$ & 5.7 & $4.3-14.9$ & 8.8 & 7.2 \\
\hline & 1 Jan-31 Dec 2015 & $\begin{array}{r}17258 \\
(98.5 \%)\end{array}$ & $0.27-4.34$ & 0.99 & $2.8-11.1$ & 5.6 & $4.2-16.2$ & 8.8 & 5.4 \\
\hline \multirow{2}{*}{$\begin{array}{l}30 \mathrm{~m} \text { water depth } \\
\left(14.307^{\circ} \mathrm{N},\right. \\
\left.74.291^{\circ} \mathrm{E}\right)\end{array}$} & 18 Apr-18 Aug 2014 & $\begin{array}{r}5829 \\
(99.7 \%)\end{array}$ & $0.47-4.38$ & 1.94 & $2.9-9.3$ & 6.0 & $5.1-13.2$ & 8.6 & 22.4 \\
\hline & 1 Jun-31 Jul 2015 & $\begin{array}{r}2928 \\
(100 \%)\end{array}$ & $0.71-5.02$ & 2.26 & $3.9-8.3$ & 6.4 & $6.2-10.8$ & 8.4 & 23.2 \\
\hline \multirow{2}{*}{$\begin{array}{l}5 \mathrm{~m} \text { water depth } \\
\left(14.304^{\circ} \mathrm{N},\right. \\
\left.74.414^{\circ} \mathrm{E}\right)\end{array}$} & 22 Apr-17 Dec 2011 & $\begin{array}{r}9751 \\
(84.6 \%)\end{array}$ & $0.26-3.67$ & 1.27 & $3.2-10.3$ & 6.4 & $5.4-16.5$ & 9.3 & 7.3 \\
\hline & 1 Jun-31 Jul 2015 & $\begin{array}{r}2801 \\
(96 \%)\end{array}$ & $0.56-4.95$ & 1.76 & $4.0-9.8$ & 6.5 & $6.1-15.8$ & 8.9 & 12.0 \\
\hline
\end{tabular}

deployed after removing the biofouling from the buoy hull and the mussel growth from the mooring line. Hence, the data available for analysis in different years varies from 90 to $99.7 \%$ except in 2013 (Table 1). At 30 and $5 \mathrm{~m}$ water depth data were collected for a limited period (Table 1), which covers pre-monsoon (low wave condition) and monsoon (high wave activity). The interannual variations in wave spectral characteristics of the study area are presented by Sanil Kumar and Anjali (2015). For studying the trends in climate, the rule of thumb is to use $\sim 30$ years of data. Since the measured data are for a short period of 6 years, the significant wave height and mean wave period from the ERA-Interim (ERA-I) reanalysis data set (Dee et al., 2011) produced by the ECMWF for points $\left(14.250^{\circ} \mathrm{N}, 74.250^{\circ} \mathrm{E}\right)$ close to the buoy location at $30 \mathrm{~m}$ water depth for 37 years (1979 to 2015) is used to study the seasonal and interannual changes in mean wave power.

The wave spectrum is obtained from the heave data recorded by the buoy through fast Fourier transform (FFT). The significant wave height $\left(H_{\mathrm{s}}\right)$ and the energy period $\left(T_{\mathrm{e}}\right)$ are obtained from the spectral moments using Eqs. (1) and (2).

$H_{\mathrm{s}}=4 \sqrt{m_{0}}$
$T_{\mathrm{e}}=\frac{m_{-1}}{m_{0}}$

Where $m_{n}$ is the $n$ th-order spectral moment and given by $m_{n}=\int_{0}^{\infty} f^{n} S(f) \mathrm{d} f, n=0$ and -1 , and $S(f)$ is the spectral energy density at frequency $f$.

\subsection{Wave power estimation}

Wave parameters are converted to the wave power transmitted per unit width by using the expression given below (Mørk et al., 2010).

$P=\rho g \int_{0}^{2 \pi} \int_{0}^{\infty} C_{\mathrm{g}}(f, d) S(f, \theta) \mathrm{d} f \mathrm{~d} \theta$

Where $P$ is the wave power per unit of crest length $\left(\mathrm{kW} \mathrm{m}^{-1}\right), \rho$ is the density of seawater $\left(\mathrm{kg} \mathrm{m}^{-3}\right), g$ is the gravitational acceleration $\left(\mathrm{m} \mathrm{s}^{-2}\right), C_{\mathrm{g}}$ is the group velocity $\left(\mathrm{m} \mathrm{s}^{-1}\right), S(f, \theta)$ is the directional wave spectrum $\left(\mathrm{m}^{2} \mathrm{~Hz}^{-1}\right)$, $d$ is the water depth $(\mathrm{m})$ and $\theta$ is the wave direction $\left({ }^{\circ}\right)$. The seawater density varies temporally based on the salinity and temperature and for the present study, an average value of $1025 \mathrm{~kg} \mathrm{~m}^{-3}$ is adopted. 

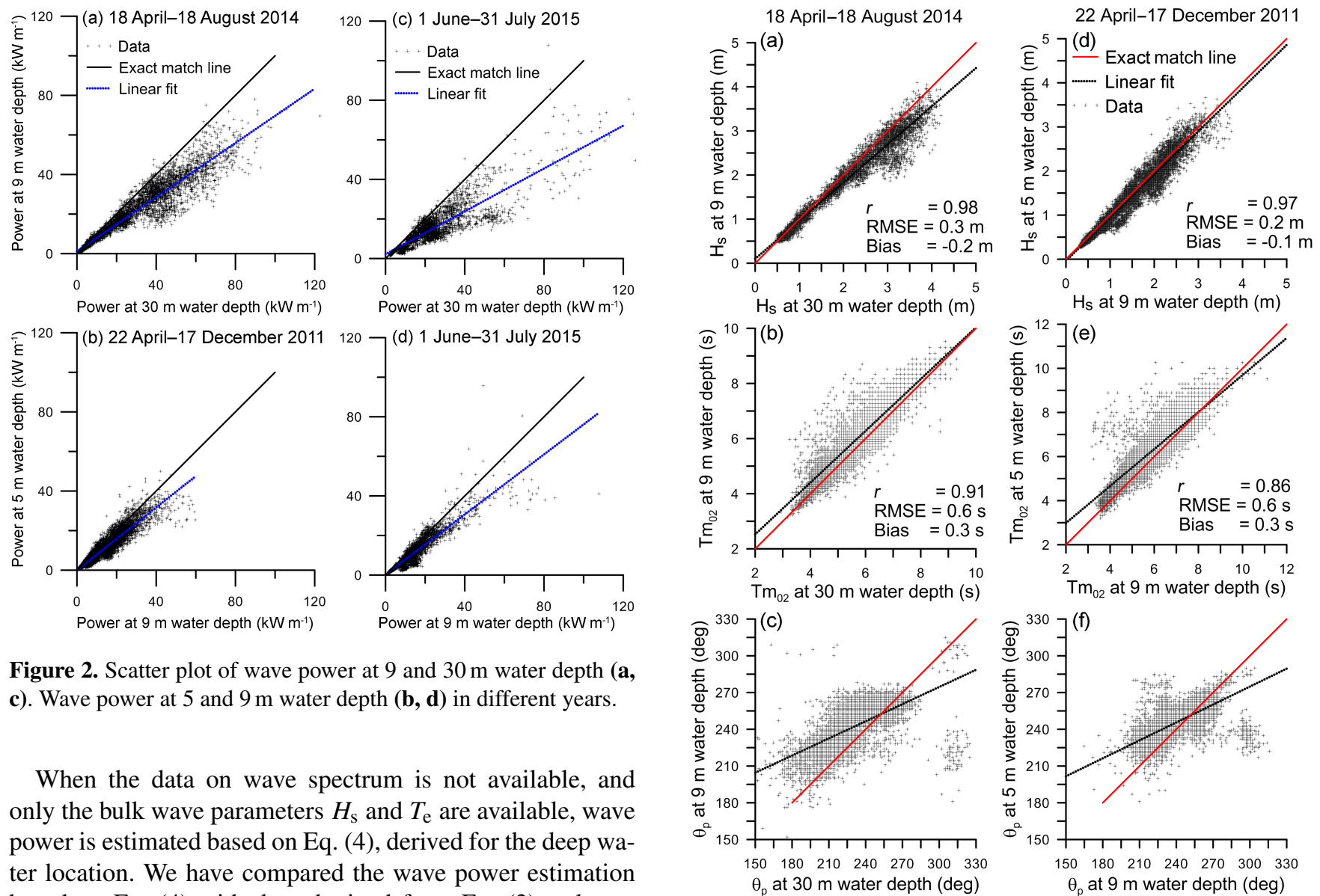

Figure 2. Scatter plot of wave power at 9 and $30 \mathrm{~m}$ water depth (a, c). Wave power at 5 and $9 \mathrm{~m}$ water depth $(\mathbf{b}, \mathbf{d})$ in different years.

When the data on wave spectrum is not available, and only the bulk wave parameters $H_{\mathrm{S}}$ and $T_{\mathrm{e}}$ are available, wave power is estimated based on Eq. (4), derived for the deep water location. We have compared the wave power estimation based on Eq. (4) with that obtained from Eq. (3) to better understand the validity of Eq. (4) in shallow waters.

$P=\frac{\rho g^{2}}{64 \pi} H_{\mathrm{s}}^{2} T_{\mathrm{e}}$

From each half-hour wave data pair $\left(H_{\mathrm{s}}, T_{\mathrm{e}}\right)$, the related wave power is computed in $\mathrm{kW} \mathrm{m}^{-1}$. The average of the power is computed in order to get the monthly and yearly mean wave power. In some of the earlier studies (Kamranzad et al., 2013; Sierra et al., 2013), since energy period $\left(T_{\mathrm{e}}\right)$ values are not readily available, the same is estimated from the peak wave period $\left(T_{\mathrm{p}}\right)$ using the expression $T_{\mathrm{e}}=0.9 T_{\mathrm{p}}$ (Contestabile et al., 2015). The validity of this equation for the study area is also examined.

Statistically the comparison between two data sets $\left(A_{i}\right.$ and $\left.B_{i}\right)$ are carried out using Pearson's linear correlation coefficient $(r)$, bias and root-mean-square error (RMSE).

$r=\frac{\sum_{i=1}^{N}\left|\left(A_{i}-\bar{A}\right)\left(B_{i}-\bar{B}\right)\right|}{\sqrt{\sum_{i=1}^{N}\left|\left(A_{i}-\bar{A}\right)^{2}\left(B_{i}-\bar{B}\right)^{2}\right|}}$

bias $=\frac{1}{N} \sum_{i=1}^{N}\left(A_{i}-B_{i}\right)$

Figure 3. Scatter plot of wave parameters at 9 and $30 \mathrm{~m}$ water depth (a) significant wave height, (b) mean wave period and (c) mean wave direction. Scatter plot of wave parameters at $5 \mathrm{~m}$ and $9 \mathrm{~m}$ water depth (d) significant wave height, (e) mean wave period and (f) mean wave direction.

$\mathrm{RMSE}=\sqrt{\frac{1}{N} \sum_{i=1}^{N}\left(A_{i}-B_{i}\right)^{2}}$

Where $N$ is the number of data points and the overbar represents the mean value.

\section{Results}

\subsection{Spatial variation of wave power}

The wave data measured simultaneously at 30 and $9 \mathrm{~m}$ water depth during 2014 and at 9 and $5 \mathrm{~m}$ water depth during 2011 and at all the three water depths during June to July 2015 are used to study the spatial variations in wave power. The horizontal distance between the locations at 30 and $9 \mathrm{~m}$ water depth is $14 \mathrm{~km}$ and the distance between the locations at 


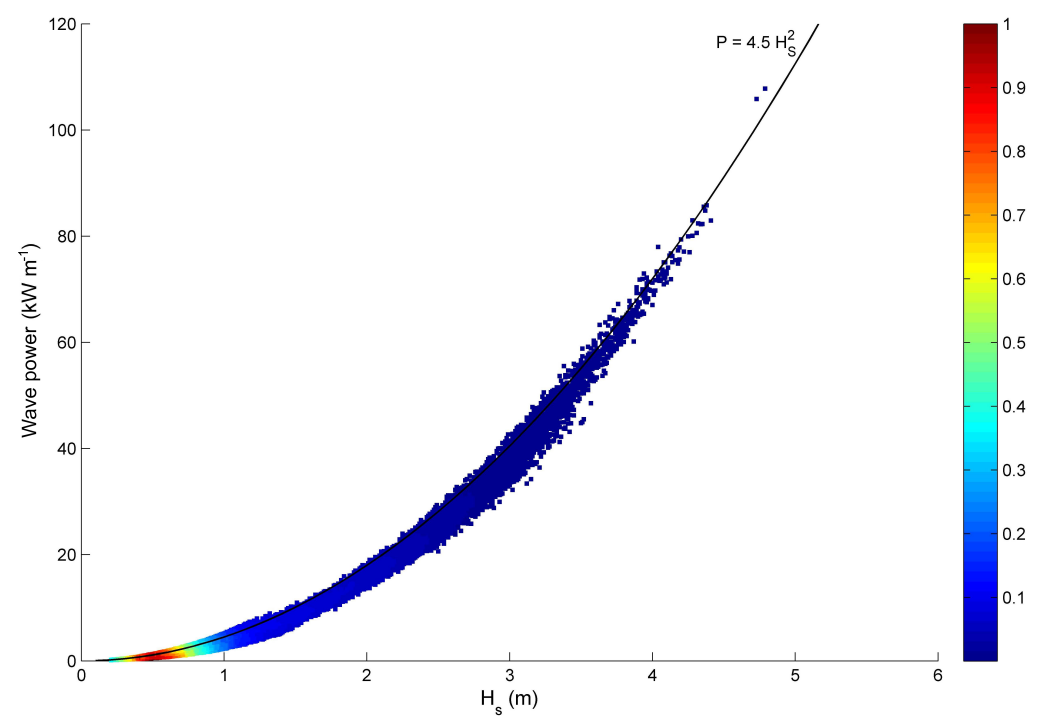

Figure 4. Variation of wave power with significant wave height at $9 \mathrm{~m}$ water depth based on measured data during 1 January 2009 to 31 December 2015. The color bar indicates the occurrence probability of the measured data.

9 and $5 \mathrm{~m}$ water depth is $2 \mathrm{~km}$. As the waves approach the coast, the waves lose energy mainly by wave breaking and by friction against the seabed. The average wave power during 18 April-18 August 2014 at 30 and $9 \mathrm{~m}$ water depth are 22.4 and $16.5 \mathrm{~kW} \mathrm{~m}^{-1}$, respectively, whereas the maximum wave power values at these depths are 122.7 and $78 \mathrm{~kW} \mathrm{~m}^{-1}$. The wave power available at $9 \mathrm{~m}$ water depth is 10 to $27 \%$ less than that at $30 \mathrm{~m}$ (Fig. 2a). The RMSE between the wave power at 30 and $9 \mathrm{~m}$ water depth is $9.8 \mathrm{~kW} \mathrm{~m}^{-1}$ and the bias is $5.9 \mathrm{~kW} \mathrm{~m}^{-1}$. Conversely, the $H_{\mathrm{s}}$ at $9 \mathrm{~m}$ water depth is approximately $15 \%$ less than the value at $30 \mathrm{~m}$ (Fig. 3a) with the mean value of 1.9 and $1.8 \mathrm{~m}$ at 30 and $9 \mathrm{~m}$ water depth, respectively. Whereas, no significant reduction is observed in mean wave period $\left(T_{\mathrm{m} 02}\right)$ at $9 \mathrm{~m}$ water depth $(\sim 6.3 \mathrm{~s}) \mathrm{com}-$ pared that at $30 \mathrm{~m}$ water depth $(\sim 6 \mathrm{~s})$ (Fig. 3b). Similarly, during 1 June to 31 July 2015 , the reduction in mean wave power from 30 to $9 \mathrm{~m}$ water depth is around $20-26 \%$ (Table 1 and Fig. 2c).

The average wave power during 22 April-17 December 2011 at 9 and $5 \mathrm{~m}$ water depth are 9.2 and $7.3 \mathrm{~kW} \mathrm{~m}^{-1}$, respectively. At $5 \mathrm{~m}$ water depth, the wave power available is $20 \%$ less than that at $9 \mathrm{~m}$ (Fig. $2 \mathrm{~b}$ ). The RMSE between the wave power at 9 and $5 \mathrm{~m}$ water depth is $3.5 \mathrm{~kW} \mathrm{~m}^{-1}$ and the bias is $1.9 \mathrm{~kW} \mathrm{~m}^{-1}$. Compared to the observation between the 30 and $9 \mathrm{~m}$ water depth, the $H_{\mathrm{s}}$ at $5 \mathrm{~m}$ water depth is only $5 \%$ less than the value at $9 \mathrm{~m}$ water depth (Fig. 3d) with a mean value of $1.3 \mathrm{~m}$ at both the 9 and $5 \mathrm{~m}$ water depth. The reduction in mean wave power from 9 to $5 \mathrm{~m}$ water depth during 1 June to 31 July 2015 is around $23 \%$ and from 30 to $5 \mathrm{~m}$ water depth is $\sim 48 \%$ (Table 1 and Fig. $2 \mathrm{~d}$ ).

Even though the wave power varies with wave height and group velocity/energy period, the variation is strongly related to $H_{\mathrm{s}}$ than other parameters since the wave power depends on the square of $H_{\mathrm{s}}$. A study by Sanil Kumar et al. (2013) showed that the wave power in the nearshore waters can be estimated approximately based on the expression $P=$ $4.5 \times H_{\mathrm{s}}^{2}$, in spite of the fact that waves in the nearshore waters will be in intermediate waters for most of the sea states. The present study also shows that if only $H_{\mathrm{s}}$ is known, wave power can be estimated using this approximate expression with a correlation coefficient of 0.99 , bias of $-0.85 \mathrm{~kW} \mathrm{~m}^{-1}$ and RMSE of $1.33 \mathrm{~kW} \mathrm{~m}^{-1}$ (Fig. 4). The mean wave power based on approximate expression is $\left(6.90 \mathrm{~kW} \mathrm{~m}^{-1}\right)$ higher than that $\left(6.05 \mathrm{~kW} \mathrm{~m}^{-1}\right)$ estimated based on wave spectrum. The wave power estimated based on the ERA-I significant wave height and wave period data is lower than the value estimated from the measured data at $30 \mathrm{~m}$ water depth for high values $\left(>20 \mathrm{~kW} \mathrm{~m}^{-1}\right)$ and the bias is $3 \mathrm{~kW} \mathrm{~m}^{-1}$ with a RMSE of $8 \mathrm{~kW} \mathrm{~m}^{-1}$ (Fig. 5). The ERA-I $H_{\mathrm{s}}$ for the same period is also lower than the measured $H_{\mathrm{S}}$ for values more than $2 \mathrm{~m}$. The mean wave period from ERA-I also shows scatter $(r=0.7)$ compared to the measured $T_{\mathrm{e}}$ data. Hence, the wave power estimate based on ERA-I can be used only as a preliminary estimate in locations in the eastern Arabian Sea where there is no measured wave data.

The wave energy period is a sea state parameter that is not readily available like $T_{\mathrm{m} 02}$ and $T_{\mathrm{p}}$. Hence, some researchers (e.g., Kamranzad et al., 2013; Contestabile et al., 2015) estimated the energy period from the peak wave period using the expression $T_{\mathrm{e}}=0.9 T_{\mathrm{p}}$. The comparison of wave power estimated based on $0.9 T_{\mathrm{p}}$ with that based on $T_{\mathrm{e}}$ using Eq. (4) shows larger scatter (Fig. 6). Sanil Kumar and Anoop (2015) observed that for locations in the Arabian Sea and the Bay of Bengal where long period swells $\left(T_{\mathrm{p}}>12 \mathrm{~s}\right)$ are present, estimating wave power using $0.9 T_{\mathrm{p}}$ as the energy period will lead to overestimation of wave power for values of $T_{\mathrm{p}}$ more 

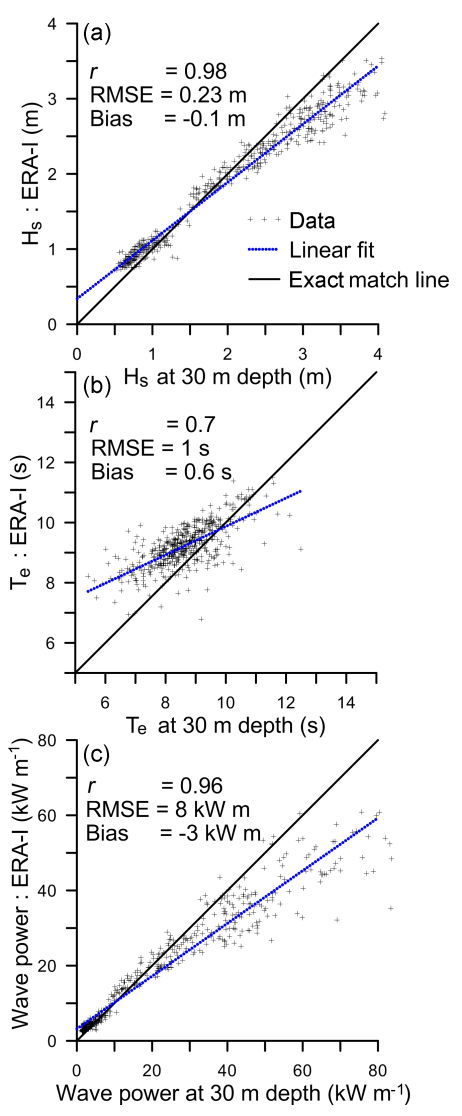

Figure 5. Scatter plot of (a) significant wave height (b) energy period and (c) wave power based on the measured data at $30 \mathrm{~m}$ water depth and that estimated from ERA-I during 19 April to $18 \mathrm{Au}-$ gust 2014.

than $10 \mathrm{~s}$ and underestimation of $T_{\mathrm{e}}$ for values of $T_{\mathrm{p}}$ less than $10 \mathrm{~s}$. In the present study area at $9 \mathrm{~m}$ water depth, during $52 \%$ of the time, $T_{\mathrm{p}}$ is more than $12 \mathrm{~s}$ with an average value of $14.3 \mathrm{~s}$ and during the same period, the average value of $T_{\mathrm{e}}$ is only $8.8 \mathrm{~s}$. Hence, large overestimation can happen if the wave power is estimated based on $T_{\mathrm{p}}$. Sanil Kumar et al. (2013) also found that the expression $T_{\mathrm{e}}=0.9 T_{\mathrm{p}}$ is not valid at four shallow water locations around India (water depth 9 to $15 \mathrm{~m}$ ) when $T_{\mathrm{p}}$ is more than $8 \mathrm{~s}$.

For the wave data considered in the study at $9 \mathrm{~m}$ water depth, intermediate and shallow water conditions exist for almost all of the time. Hence, the wave power estimated based on the deep water Eq. (4) is $\sim 10 \%$ more than that estimated based on Eq. (3) using the measured data (Fig. 6). Here, $H_{\mathrm{s}}$ and $T_{\mathrm{e}}$ were obtained from the wave spectrum of the buoy measured data. The study shows that the wave power estimate based on approximate Eq. (4) using only the $H_{\mathrm{s}}$ and $T_{\mathrm{e}}$ will lead to overestimation of wave power in shallow waters.

It is observed that the distribution of $H_{\mathrm{S}}$ with respect to $T_{\mathrm{e}}$ follows mainly two patterns: (i) a narrow distribution of $T_{\mathrm{e}}$ (7-11 s) for a wide range of $H_{\mathrm{S}}$ values $(0.5-4.5 \mathrm{~m})$ and (ii) a broad distribution of $T_{\mathrm{e}}(4-16 \mathrm{~s})$ for a narrow range of $H_{\mathrm{s}}$

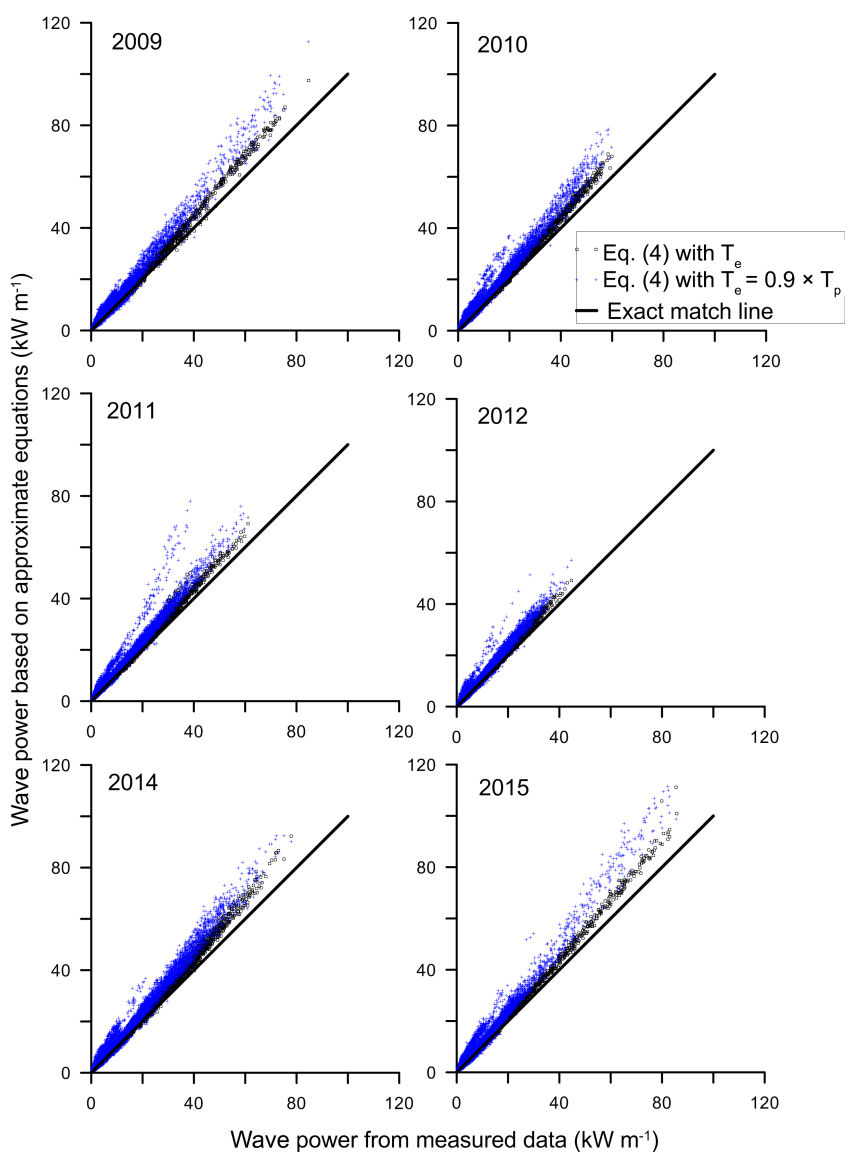

Figure 6. Scatter plot of wave power based on the measured data at $9 \mathrm{~m}$ water depth and that estimated from Eq. (4) with $T_{\mathrm{e}}$ and $T_{\mathrm{e}}=$ $0.9 T_{\mathrm{p}}$ during January to December in different years.

(Fig. 7). The narrow distribution of $T_{\mathrm{e}}$ is during the monsoon period and the broad distribution of $T_{\mathrm{e}}$ is during the nonmonsoon period when the $H_{\mathrm{s}}$ is less than $1.5 \mathrm{~m}$.

Daily variation in wave power varied from 0.1 to $37 \mathrm{~kW} \mathrm{~m}^{-1}$ with an average value of $3.7 \mathrm{~kW} \mathrm{~m}^{-1}$ (Fig. 8). Sanil Kumar et al. (2013) observed a daily variation in wave power from 0.2 to $40 \mathrm{~kW} \mathrm{~m}^{-1}$ and the average daily wave power from 0.4 to $56 \mathrm{~kW} \mathrm{~m}^{-1}$ for coastal locations around India. This large variation in daily wave power is due to the influence of monsoon, which creates a large difference in daily wave height (daily average $H_{\mathrm{s}}$ varying from 0.1 to $1.8 \mathrm{~m}$ ) and wave period. Earlier studies off the west coast of India show diurnal variation in bulk wave parameters due to the sea breeze mainly during the pre-monsoon (Sanil Kumar and Anjali, 2015). The change in wave power due to the sea breeze is studied through the plot of hourly averaged wave power with time in different months (Fig. 9). Figure 9 indicates that during January to May and December, due to the sea breeze, the wave power is highest during 16:0018:00 UTC. 


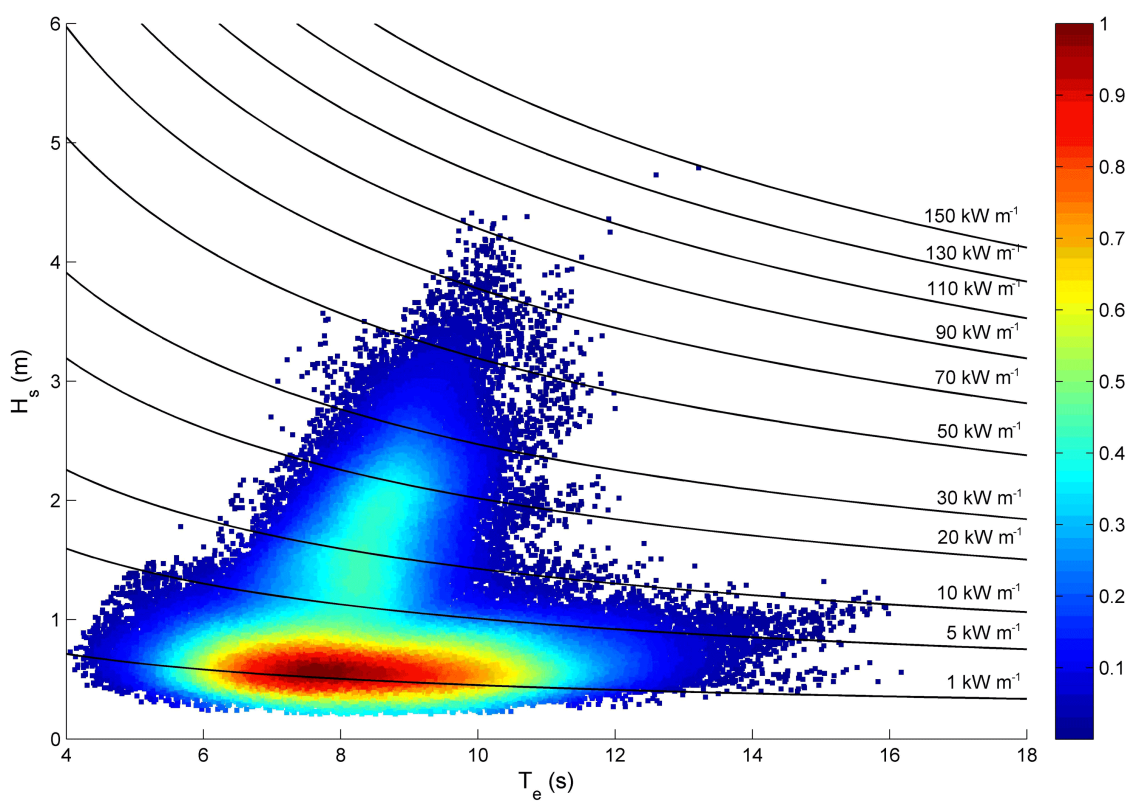

Figure 7. Scatter plot of significant wave height with energy period at $9 \mathrm{~m}$ water depth during January 2009 to December 2015 . The color bar indicates the occurrence probability of the measured data.

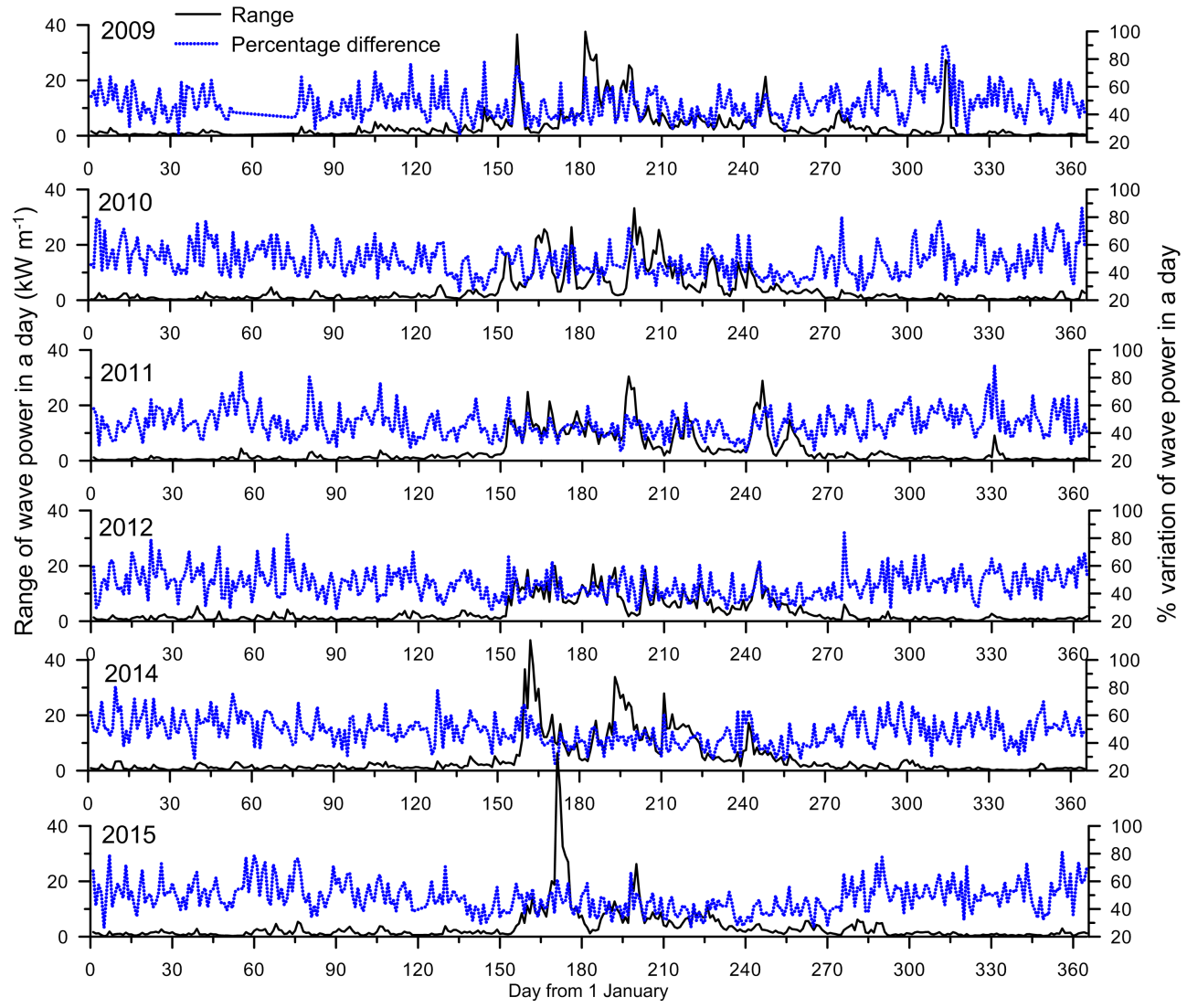

Figure 8. Range and percentage variation of wave power in a given day in different years. 

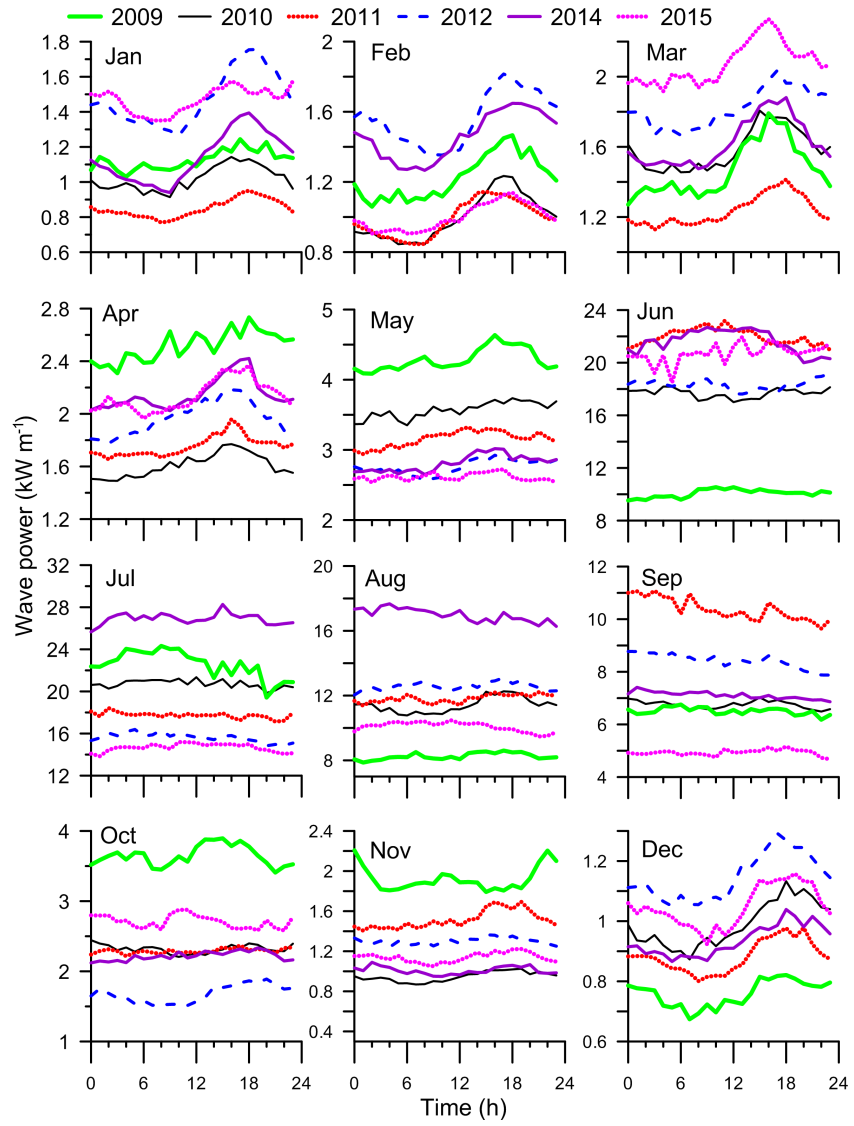

Figure 9. Hourly variation of mean wave power in different months.

\subsection{Monthly variations in wave power at $9 \mathrm{~m}$ water depth}

The monthly average wave power variation in different years at $9 \mathrm{~m}$ water depth is presented in Fig. 10. Monthly average wave power varies from $1 \mathrm{~kW} \mathrm{~m}^{-1}$ in December to $19.7 \mathrm{~kW} \mathrm{~m}^{-1}$ in July. In all years, the monthly mean wave power is highest during the months of June or July. During 2009-2015, the highest monthly mean wave power $\left(\sim 26.9 \mathrm{~kW} \mathrm{~m}^{-1}\right)$ occurred in July 2014 . The mean wave power during June-August is more than $25 \mathrm{~kW} \mathrm{~m}^{-1}$ at deepwater locations (Sanil Kumar and Anoop, 2015). For the study location during the non-monsoon period, the average monthly wave power is less than $5 \mathrm{~kW} \mathrm{~m}^{-1}$ in all years. To determine the monthly variability in wave power, the monthly variability index (MVI) is used (Cornett, 2008). The MVI is the ratio of the difference between the maximum and minimum monthly average wave power and the annual average wave power. The present study indicates that the wave power variability is greater in all years with MVI values ranging from 3 to 3.8. Small values of the MVI indicate less variability in wave power.

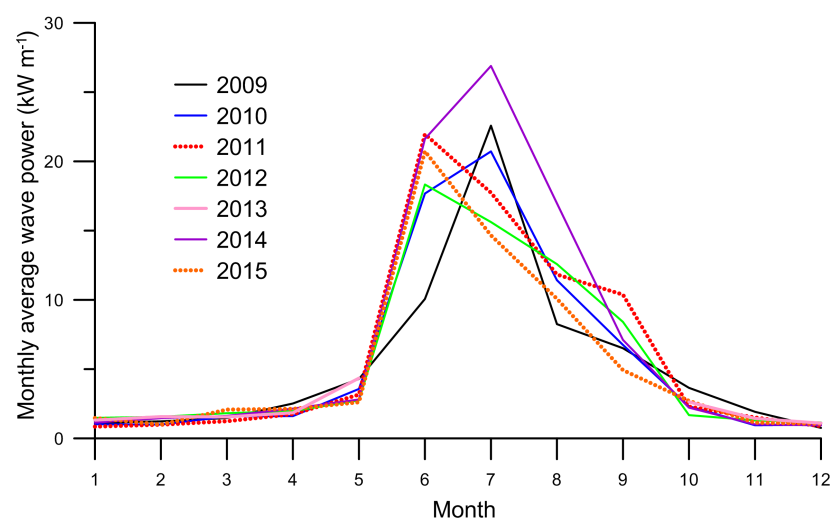

Figure 10. Monthly average wave power in different years at $9 \mathrm{~m}$ water depth

\subsection{Seasonal variations in wave power at $9 \mathrm{~m}$ water depth}

The waves in the Indian shelf seas show seasonal variations (Glejin et al., 2013; Sajiv et al., 2012) with high waves $\left(H_{\mathrm{s}}>1.5 \mathrm{~m}\right)$ during the monsoon. February to May is the pre-monsoon period, while October to January is the postmonsoon period. Hence, the seasonal variations in wave power are examined and the findings show that the highest seasonal mean wave power occurs during the monsoon (Table 2). The average wave power during the monsoon varied from $12.6 \mathrm{~kW} \mathrm{~m}^{-1}$ (in 2015) to $18.2 \mathrm{~kW} \mathrm{~m}^{-1}$ (in 2014) (Table 2). The study based on ERA-I data at $30 \mathrm{~m}$ water depth shows that the average wave power during the monsoon period varied from $15.54 \mathrm{~kW} \mathrm{~m}^{-1}$ (in 1987) to $26.08 \mathrm{~kW} \mathrm{~m}^{-1}$ (in 1994) with an average value of $20.75 \mathrm{~kW} \mathrm{~m}^{-1}$. At $9 \mathrm{~m}$ water depth, the seasonal average wave power varied from 1.97 to $2.98 \mathrm{~kW} \mathrm{~m}^{-1}$ during the pre-monsoon and 1.33 to $2.04 \mathrm{~kW} \mathrm{~m}^{-1}$ during the post-monsoon (Table 2).

\subsection{Interannual variations in wave power at $9 \mathrm{~m}$ water depth}

Interannual variations in wave climate are reported in many studies (Gulev and Grigorieva, 2004; Shanas and Sanil Kumar, 2014). When further investigating the correlation between the available wave power in different years, it was found that the annual mean wave power was identical $\left(\sim 5.8 \mathrm{~kW} \mathrm{~m}^{-1}\right)$ in 3 out of 6 years studied at $9 \mathrm{~m}$ water depth. Compared to the other years, the annual mean $H_{\mathrm{s}}$ and $T_{\mathrm{e}}$ are maximum (1.08 $\mathrm{m}$ and $\left.8.8 \mathrm{~s}\right)$ in 2014 and hence the annual mean wave power is also high $\left(\sim 7.2 \mathrm{~kW} \mathrm{~m}^{-1}\right)$ in 2014 . The percentage distribution of wave power available in different ranges during an annual cycle in different years are presented in Table 3. The table shows that, in all years, wave power more than $10 \mathrm{~kW} \mathrm{~m}^{-1}$ is available during $16 \%$ (2015) to $22 \%$ (2012) in a year. The study shows that the interannual variations in annual mean wave power $\left(\sim 6 \mathrm{~kW} \mathrm{~m}^{-1}\right)$ 
Table 2. Range and average value of the wave power at $9 \mathrm{~m}$ water depth during different seasons of different years.

\begin{tabular}{|c|c|c|c|c|c|c|c|c|}
\hline \multirow[t]{3}{*}{ Year } & \multicolumn{8}{|c|}{ Wave power $\left(\mathrm{kW} \mathrm{m}^{-1}\right)$} \\
\hline & \multicolumn{2}{|c|}{ Pre-monsoon (FMAM) } & \multicolumn{2}{|c|}{ Monsoon (JJAS) } & \multicolumn{2}{|c|}{ Post-monsoon (ONDJ) } & \multicolumn{2}{|c|}{ Full year } \\
\hline & Range & Average & Range & Average & Range & Average & Range & Average \\
\hline 2009 & $0.40-19.62$ & 2.98 & $1.20-97.40$ & 12.87 & $0.16-31.70$ & 2.04 & $0.14-84.81$ & 5.78 \\
\hline 2010 & $0.30-12.86$ & 2.19 & $0.92-68.93$ & 15.57 & $0.19-8.03$ & 1.42 & $0.17-59.94$ & 5.83 \\
\hline 2011 & $0.29-7.36$ & 2.00 & $1.59-69.21$ & 16.94 & $0.28-10.82$ & 1.60 & $0.24-61.20$ & 6.26 \\
\hline 2012 & $0.41-9.26$ & 2.22 & $1.04-49.24$ & 14.88 & $0.34-7.76$ & 1.58 & $0.29-44.69$ & 5.74 \\
\hline 2013 & $0.33-10.28$ & 2.36 & - & - & $0.27-10.61$ & 1.62 & - & - \\
\hline 2014 & $0.38-8.29$ & 2.02 & $1.19-77.95$ & 18.21 & $0.2-8.16$ & 1.33 & $0.2-77.95$ & 7.23 \\
\hline 2015 & $0.29-7.14$ & 1.97 & $1.35-107.78$ & 12.59 & $0.29-11.12$ & 1.60 & $0.29-108.78$ & 5.44 \\
\hline
\end{tabular}

during 2009 to 2015 at $9 \mathrm{~m}$ water depth based on measured data are 3.8 to $19.3 \%$ (Table 2). The interannual variations in wave power are due to the interannual variations in the wave spectrum observed in all months with larger variations during January-February, May and October-November as a result of the variations in the wind-sea and the swells propagating from the southern Indian Ocean (Glejin et al., 2013; Sanil Kumar and Anjali, 2015). The study based on ERA-I data at $30 \mathrm{~m}$ water depth shows that the average annual wave power varied from $7.18 \mathrm{~kW} \mathrm{~m}^{-1}$ (in 1987) to $10.69 \mathrm{~kW} \mathrm{~m}^{-1}$ (in 1994) with an average value of $8.98 \mathrm{~kW} \mathrm{~m}^{-1}$ (Fig. 11).

\subsection{Directional distribution of wave power at $9 \mathrm{~m}$ water depth}

The directional distribution of wave power is required when selecting the orientation of a wave power plant. At $9 \mathrm{~m}$ water depth, the high wave energy $\left(>20 \mathrm{~kW} \mathrm{~m}^{-1}\right)$ is essentially from the $245-270^{\circ}$ sector and less energetic waves are in the direction between 225 and $245^{\circ}$ (Fig. 12). Nearly $75 \%$ of the total annual wave energy is from the direction between 245 and $270^{\circ}$. At the study location, the inclination of the coast is $17^{\circ}$ to the west with respect to true north. Depth contours appear as almost parallel with the $10 \mathrm{~m}$ contour occurring at an average distance of $3.5 \mathrm{~km}$ from the coast. The wave direction of $253^{\circ}$ corresponds to the waves approaching parallel to the coastline. Hence, due to refraction, most of the waves are approaching the measurement location at $9 \mathrm{~m}$ water depth in a narrow range of $25^{\circ}$ indicating that the wave directional scatter of the energy is less in the nearshore waters. The high wave power $\left(>10 \mathrm{~kW} \mathrm{~m}^{-1}\right)$ in shallow waters along the west coast of India is due to the southwesterly $\left(250-270^{\circ}\right)$ waves and occurred during the monsoon period (Sanil Kumar et al., 2013).

\section{Discussions}

The above analysis using measured and reanalysis data indicates the seasonal and interannual variations in wave power. Even though the marine environment off the west coast of

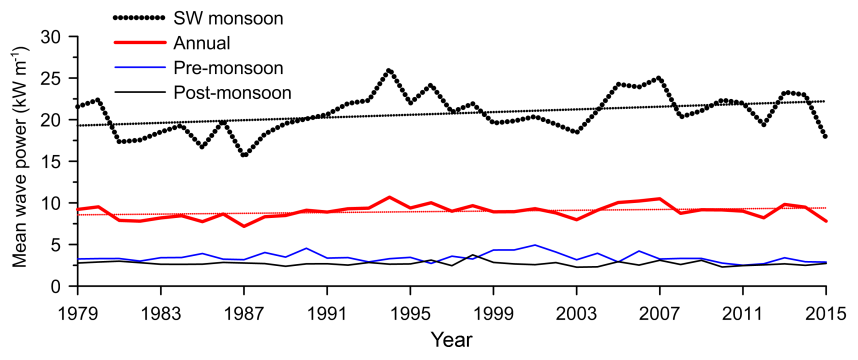

Figure 11. Seasonal and annual mean wave power from 1979 to 2015 at $30 \mathrm{~m}$ water depth estimated based on ERA-I significant wave height and wave period data

India is not severe like the conditions in the Gulf of Mexico and the North Sea (Arinaga and Cheung, 2012), during the monsoon period significant wave height in the study area reaches a maximum of $5 \mathrm{~m}$. At $9 \mathrm{~m}$ water depth, the wave energy is concentrated in the classes over a range of $0.5-1 \mathrm{~m}$ with respect to $H_{\mathrm{s}}$ and between 6 and $10 \mathrm{~s}$ with respect to the $T_{\mathrm{e}}$, with an annual occurrence of $31.38 \%$ (approximately 114 days in a year). The global study by Arinaga and Cheung (2012) reported very high monthly median wave power $\left(\sim 72 \mathrm{~kW} \mathrm{~m}^{-1}\right)$ in the Arabian Sea in July, whereas, based on measured data, the median wave power during July at $9 \mathrm{~m}$ water depth is $16.7 \mathrm{~kW} \mathrm{~m}^{-1}$. Anoop et al. (2015) have shown that the intensity of waves in the Arabian Sea is higher (average wave height $\sim 3$ to $3.5 \mathrm{~m}$ ) on the western side than that ( $\sim 2$ to $2.5 \mathrm{~m}$ ) on the eastern side during monsoon season as a result of the strong southwesterly winds.

The wave power during the monsoon is $74-90 \%$ of the annual wave power in different years. Sanil Kumar et al. (2013) reported that along the west coast of India, $83-85 \%$ of the annual wave power is during the monsoon period and the mean wave power is also high $\left(15.5-19.3 \mathrm{~kW} \mathrm{~m}^{-1}\right)$ during the monsoon. Sanil Kumar and Anoop (2015) observed that along the western shelf seas of India, most of the wave power is available during the monsoon period when the availability of solar power is less due to cloud cover; and during the nonmonsoon periods, the availability of solar power is high when 
Table 3. Percentage of waves in different wave power ranges along with average significant wave height, average energy period and average wave power in different years and in different groups.

\begin{tabular}{|c|c|c|c|c|c|}
\hline Year & $\begin{array}{r}\text { Wave } \\
\text { power } \\
\left(\mathrm{kW} \mathrm{m}^{-1}\right)\end{array}$ & $\begin{array}{r}\text { Average } \\
\text { significant } \\
\text { wave height, } \\
H_{\mathrm{S}}(\mathrm{m})\end{array}$ & $\begin{array}{r}\text { Average } \\
\text { energy } \\
\text { period, } \\
T_{\mathrm{e}}(\mathrm{s})\end{array}$ & $\begin{array}{r}\text { Average } \\
\text { wave } \\
\text { power } \\
\left(\mathrm{kW} \mathrm{m}^{-1}\right)\end{array}$ & $\begin{array}{r}\text { Percentage } \\
\text { occurrence } \\
(\%)\end{array}$ \\
\hline \multirow[t]{3}{*}{2009} & $<5$ & 0.7 & 8.6 & 1.8 & 67.1 \\
\hline & $5-10$ & 1.4 & 8.1 & 7.3 & 15.7 \\
\hline & $>10$ & 2.2 & 8.6 & 19.8 & 17.2 \\
\hline \multirow[t]{3}{*}{2010} & $<5$ & 0.6 & 8.1 & 1.6 & 69.1 \\
\hline & $5-10$ & 1.4 & 8.4 & 7.4 & 14.1 \\
\hline & $>10$ & 2.3 & 9.1 & 21.9 & 16.8 \\
\hline \multirow[t]{3}{*}{2011} & $<5$ & 0.6 & 8.4 & 1.6 & 68.7 \\
\hline & $5-10$ & 1.4 & 8.7 & 7.3 & 10.3 \\
\hline & $>10$ & 2.3 & 8.9 & 21.1 & 21.0 \\
\hline \multirow[t]{3}{*}{2012} & $<5$ & 0.7 & 8.3 & 1.7 & 69.2 \\
\hline & $5-10$ & 1.4 & 8.0 & 7.3 & 8.6 \\
\hline & $>10$ & 2.1 & 8.8 & 17.6 & 22.2 \\
\hline \multirow[t]{3}{*}{2014} & $<5$ & 0.7 & 8.7 & 1.7 & 70.4 \\
\hline & $5-10$ & 1.4 & 9.0 & 7.3 & 8.7 \\
\hline & $>10$ & 2.4 & 9.1 & 25.6 & 20.9 \\
\hline \multirow[t]{3}{*}{2015} & $<5$ & 0.7 & 8.8 & 1.8 & 71.7 \\
\hline & $5-10$ & 1.3 & 8.5 & 6.9 & 12.4 \\
\hline & $>10$ & 2.2 & 8.9 & 20.6 & 15.9 \\
\hline
\end{tabular}

the wave power is less. Hence, it would be ideal to build a combined wave and solar power plant at the location studied.

During the pre-monsoon period, the wave power is 9 to $17 \%$ of the annual wave power and the wave power during the post-monsoon period is 6 to $11 \%$ of the annual wave power in different years. The strong seasonality observed in the wave power is similar to the variations observed in significant wave height along the eastern Arabian Sea (Shanas and Sanil Kumar, 2014; Anoop et al., 2015). Seasonal variability in wave parameters is observed in most of the oceans (Portilla et al., 2013; McArthur and Brekken, 2010; Rusu, 2014; Rusu and Onea, 2015). Even though high seasonal variability of wave power $\left(1-19.7 \mathrm{~kW} \mathrm{~m}^{-1}\right)$ is observed in the study area, the variability is less than the seasonal variability observed in the North Atlantic. Monthly mean wave power in the North Atlantic varied from $\sim 10 \mathrm{~kW} \mathrm{~m}^{-1}$ in July to $\sim 90 \mathrm{~kW} \mathrm{~m}^{-1}$ in January with an annual mean value of $\sim 45 \mathrm{~kW} \mathrm{~m}^{-1}$ (Barstow et al., 2008). Along the east coast of the United States, the wave power resource tends to be much larger in the winter $\left(50 \mathrm{~kW} \mathrm{~m}^{-1}\right)$ than in the summer $\left(10 \mathrm{~kW} \mathrm{~m}^{-1}\right)$ (Sierra et al., 2013). A clear analogy can be seen between the high seasonal variability of wave power along the central west coast of India and that along the European shelf seas and the east coast of the United States.

Sanil Kumar and Anoop (2015) observed that the annual average wave power is relatively high $\left(\sim 12 \mathrm{~kW} \mathrm{~m}^{-1}\right)$ in the

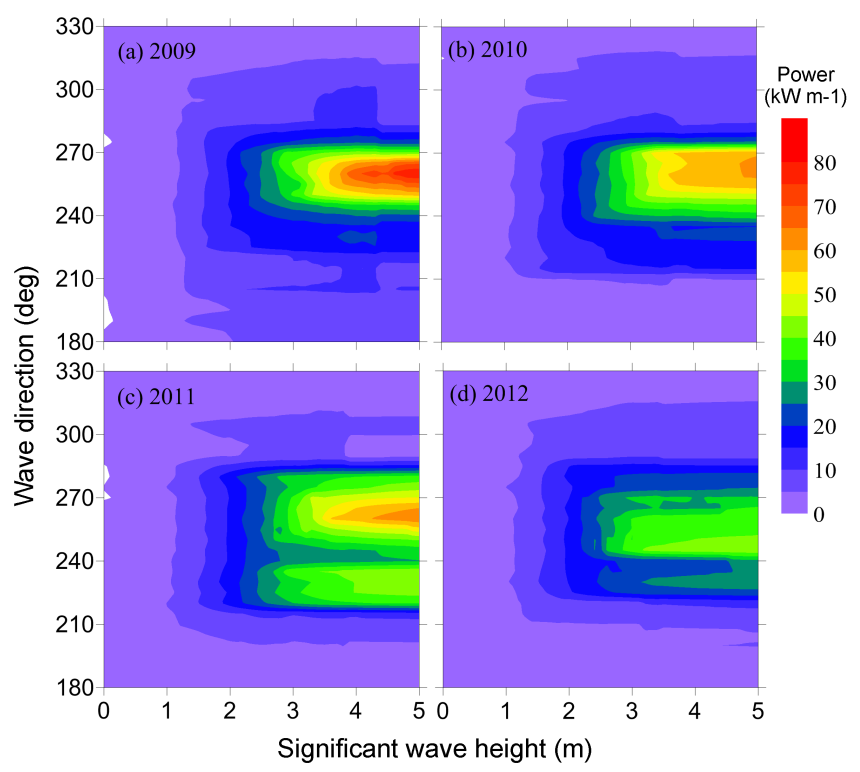

Figure 12. Hovmöller diagram of the distribution of wave power with significant wave height and wave direction at $9 \mathrm{~m}$ water depth from 2009 to 2012. 
central Arabian Sea and off the southern tip of India and the average annual wave power along the western shelf seas of India is $7.9-11.3 \mathrm{~kW} \mathrm{~m}^{-1}$. In the Southern Hemisphere, the maximum annual mean wave power is $\sim 125 \mathrm{~kW} \mathrm{~m}^{-1}$ near $48^{\circ} \mathrm{S}, 94^{\circ} \mathrm{E}$, southwest of Australia (Barstow et al., 2008); and in the Northern Hemisphere, the annual mean wave power south of Iceland (Barstow et al., 2008) exceeds $80 \mathrm{~kW} \mathrm{~m}^{-1}$ at around $56^{\circ} \mathrm{N}, 19^{\circ} \mathrm{W}$. Averaged over years, offshore wave power levels in the range of $30-100 \mathrm{~kW} \mathrm{~m}^{-1}$ are found at latitudes $40-50^{\circ}$; and less power levels further north and south as well as in most tropical waters have an average wave power level of below $20 \mathrm{~kW} \mathrm{~m}^{-1}$ (Falnes, 2007).

The ratio of the annual maximum significant wave height to the annual average significant wave height is a measure for the feasibility of the energy project (Barstow et al., 2008). The annual mean wave height determines the annual mean wave power availability, whereas the annual maximum significant wave height determines the design parameter for the wave power plant and influences the investment cost. The ratio of the annual maximum significant wave height to the annual mean significant wave height at $9 \mathrm{~m}$ water depth varied from 3.3 to 4.2 in different years. Locations with low values of this ratio favor setting up the wave energy plant and high values of the ratio will lead to large investment cost (Barstow et al., 2008). High values for the ratio of the annual maximum significant wave height to the annual mean significant wave height are observed in locations affected by tropical cyclones. The wave characteristics in the open ocean vary significantly if the area is frequented by tropical cyclones and storms. In such areas, the wave energy converters are to be designed for very high waves and will lead to large investment costs and can lead to economic impacts in case of failure. The examination of wave data at $30 \mathrm{~m}$ water depth during 1979 to 2015 shows that the interannual variations in the annual mean $H_{\mathrm{s}}$ are less than $6 \%$ and large variations in wave characteristics are not observed in the study area. During 1979 to 2015 , the interannual variations in annual mean wave power at $30 \mathrm{~m}$ water depth are within $20 \%$.

\section{Concluding remarks}

The temporal and spatial variability of the wave power in the nearshore waters of the eastern Arabian Sea are examined based on data collected at three locations. At $9 \mathrm{~m}$ water depth, the wave power is more than $10 \mathrm{~kW} \mathrm{~m}^{-1}$ during $17-22 \%$ of the time in a year and the mean wave power during June-August measures more than $12 \mathrm{~kW} \mathrm{~m}^{-1}$. During the non-monsoon period, the mean monthly wave power is less than $5 \mathrm{~kW} \mathrm{~m}^{-1}$ in all years. The attenuation in wave height is $15 \%$ from 30 to $9 \mathrm{~m}$ and $5 \%$ from 9 to $5 \mathrm{~m}$, but the wave power available at $9 \mathrm{~m}$ water depth is 10 to $27 \%$ less than that at $30 \mathrm{~m}$ and the wave power available at $5 \mathrm{~m}$ water depth is 20 to $23 \%$ less than that at $9 \mathrm{~m}$. The wave power estimated based on the ERA-I data are lower than the value estimated from the measured data at $30 \mathrm{~m}$ water depth for high values $\left(>20 \mathrm{~kW} \mathrm{~m}^{-1}\right)$ with a bias of $3 \mathrm{~kW} \mathrm{~m}^{-1}$. At $9 \mathrm{~m}$ water depth, during $52 \%$ of the time, peak wave period is more than $12 \mathrm{~s}$ with an average value of $14.3 \mathrm{~s}$ and during the same period, the average value of energy period is only $8.8 \mathrm{~s}$ and hence estimating wave power based on peak wave period will lead to large overestimation. The interannual variations in annual mean wave power (at $30 \mathrm{~m}$ water depth) during 1979 to 2015 is within $20 \%$ and large changes are not observed. The spread of incoming wave directions is more concentrated within a narrow band $\left(\sim 25^{\circ}\right)$ at the shallower water depths due to refraction and is advantageous for the capture of energy. The wave power estimation based on bulk wave parameters obtained either from measurements, numerical modeling or reanalysis data (ERA-I) will provide an approximate estimate of wave power at a location and can only be used as a preliminary estimate. The wave power estimate presented in this paper based on the wave spectrum from the measured wave data can be used for planning wave energy converters.

\section{Data availability}

The measured wave data used in the study can be requested from the corresponding author for joint research work. The long-term data on significant wave height and wave period are from the ERA-Interim global atmospheric reanalysis data set of the ECMWF and are available at http://www.ecmwf. int/en/research/climate-reanalysis/era-interim (Dee et al., 2011).

Acknowledgements. Director, CSIR-NIO, Goa, provided facilities to carry out the study. The Council of Scientific and Industrial Research, New Delhi, funded the research program. Shri Jai Singh, Technical Officer, CSIR-NIO, assisted in the data analysis. This work forms part of the PhD thesis of the first author and the CSIRNIO contribution number is 5969.

The topical editor, M. Salzmann, thanks two anonymous referees for their help in evaluating this paper.

\section{References}

Anoop, T. R., Sanil Kumar, V., Shanas, P. R., and Glejin, J.: Surface wave climatology and its variability in the North Indian Ocean based on ERA-Interim reanalysis, J. Atmos. Ocean. Tech., 32, 1372-1385, doi:10.1175/JTECH-D-14-00212.1, 2015.

Appendini, C. M., Urbano-Latorre, C. P., Figueroa, B., Dagua-Paz, C. J., Torres-Freyermuth, A., and Salles, P.: Wave energy potential assessment in the Caribbean Low Level Jet using wave hindcast information, Appl. Energy, 137, 375-384, 2015.

Arinaga, R. A. and Cheung, K. F.: Atlas of global wave energy from 10 years of reanalysis and hindcast data, Renew. Energ., 39, 4964, 2012.

Barstow, S., Mørk, G., Mollison, D., and Cruz, J.: The wave energy resource, in: Ocean Wave Energy: current status and future 
prepectives, edited by: Cruz, J., Berlin, Heidelber, Springer, 93132,2008

Cavaleri, L.: Wave models and input wind, in: Dynamics and Modelling of Ocean Waves, edited by: Komen, G. K., Cavaleri, L., Donelan, M., Hasselmann, K., Hasselmann, S., and Janssen, P. A. E. M., Cambridge University Press, 259-378, 1994.

Clement, P., McCullen, A., Falcao, A., Fiorentino, F., Gardner Hammarlund, K.: Wave energy Europe: current status and perspectives, Renew. Sust. Energ. Rev., 6, 405-431, 2002.

Contestabile, P., Ferrante, V., and Vicinanza, D.: Wave Energy Resource along the Coast of Santa Catarina (Brazil), Energies 8, 14219-14243, 2015.

Cornett, A. M.: A global wave energy resource assessment, In International offshore and polar engineering conference, Vancouver, Canada, 318-326, 2008.

Dee, D. P., Uppala, S. M., Simmons, A. J., Berrisford, P., Poli, P., Kobayashi, S., Andrae, U., Balmaseda, M. A., Balsamo, G., Bauer, P., Bechtold, P., Beljaars, A. C. M., van de Berg, L., Bidlot, J., Bormann, N., Delsol, C., Dragani, R., Fuentes, M., Geer, A. J., Haimberger, L., Healy, S. B., Hersbach, H., Hólm, E. V., Isaksen, L., Kållberg, P., Köhler, M., Matricardi, M., McNally, A. P., Monge-Sanz, B. M., Morcrette, J.-J., Park, B.-K., Peubey, C., de Rosnay, P., Tavolato, C., Thépaut, J.-N., and Vitart, F.: The ERA-Interim reanalysis: configuration and performance of the data assimilation system, Q. J. Roy. Meteor. Soc., 137, 553-597, 2011.

Defne, Z., Haas, K. A., and Fritz, H. M.: Wave power potential along the Atlantic coast of the southeastern USA, Renew. Energ., 34, 2197-2205, 2009.

Falcao, A. F. O. and Henriques, J. C. C.: Oscillating-water-column wave energy converters and air turbines: A review, Renew. Energ., 85, 1391-1424, 2016.

Falnes, J.: A review of wave-energy extraction, Mar. Struct., 20, 185-201, 2007.

Gallagher, S., Tiron, R., Whelan, E., Gleeson, E., Dias, F., and McGrath, R.: The nearshore wind and wave energy potential of Ireland: a high resolution assessment of availability and accessibility, Renew. Energ., 88, 494-516, 2016.

Glejin, J., Sanil Kumar, V., Balakrishnan Nair, T. M., and Singh, J.: Influence of winds on temporally varying short and long period gravity waves in the near shore regions of the eastern Arabian Sea, Ocean Sci., 9, 343-353, doi:10.5194/os-9-343-2013, 2013.

Gonçalves, M., Martinho, P., and Soares, C. G.: Assessment of wave energy in the Canary Islands, Renew. Energ., 68, 774-784, 2014.

Gulev, S. K. and Grigorieva, V.: Last century changes in ocean wind wave height from global visual wave data, Geophys. Res. Lett., 31, L24302, doi:10.1029/2004GL021040, 2004.

Henderson, R.: Design, simulation, and testing of a novel hydraulic power take-off system for the Pelamis wave energy converter, Energy, 31, 271-283, 2006.

IEA: International Energy Agency, $\mathrm{CO}_{2}$ emissions from fuel combustion - highlights (2013 Edition), OECD/IEA, France, 2013.

Kamranzad, B., Etemad-shahidi, A., and Chegini, V.: Assessment of wave energy variation in the Persian Gulf, Ocean Eng., 70, 72-80, 2013.

Kofoed, J. P., Frigaard, P., Friis-Madsen, E., and Sørensen, H. C.: Prototype Testing of the Wave Energy Converter Wave Dragon, Renew. Energ., 31, 181-189, 2006.
Mala, K., Jayaraj, J., Jayashankar, V., Muruganandam, T. M., Santhakumar, S., Ravindran, M., Takao, M., Setoguchi, T., Toyota, K., and Nagata, S.: A twin unidirectional impulse turbine topology for OWC based wave energy plants - Experimental validation and scaling, Renew. Energ., 36, 307-314, 2011.

McArthur, S. and Brekken, T.: Ocean wave power data generation for grid integration studies, IEEE Power and Energy Society general Meeting, 1-6, doi:10.1109/PES.2010.5589711, Institute of Electrical and Electronics Engineers, New York, USA, 2010.

Mørk, G., Barstow, S., Kabuth, A., and Pontes, M. T.: Assessing the global wave energy potential, Proceedings of OMAE2010, 29th International Conference on Ocean, Offshore Mechanics and Arctic Engineering, 6-11 June, Shanghai, China, 2010.

Portilla, J., Sosa, J., and Cavaleri, L.: Wave energy resources: Wave climate and exploitation, Renew. Energ., 57, 594-605, 2013.

Ravindran, M. and Koola, P. M.: Energy from sea waves - the Indian wave energy programme, Curr. Sci. India, 60, 676-680, 1991.

Rusu, E.: Evaluation of the wave energy conversion efficiency in various coastal environments, Energies, 7, 4002-4018, 2014.

Rusu, L.: Assessment of the Wave Energy in the Black Sea Based on a 15-Year Hindcast with Data Assimilation, Energies, 9, 1037010388, 2015.

Rusu, L. and Onea, F.: Assessment of the performances of various wave energy converters along the European continental coasts, Energy, 82, 889-904, 2015.

Sajiv, P. C., Sanil Kumar, V., Glejin, J., Dora, G. U., and Vinayaraj, P.: Interannual and seasonal variations in near shore wave characteristics off Honnavar, west coast of India, Curr. Sci., 103, 286292, 2012

Saket, A. and Etemad-Shahidi, A.: Wave energy potential along the northern coasts of the Gulf of Oman, Iran, Renew. Energ., 40, 90-97, 2012.

Sanil Kumar, V. and Anjali Nair, M.: Inter-annual variations in wave spectral characteristics at a location off the central west coast of India, Ann. Geophys., 33, 159-167, doi:10.5194/angeo-33-1592015, 2015.

Sanil Kumar, V. and Anoop, T. R.: Wave energy resource assessment for the Indian shelf seas, Renew. Energ., 76, 212-219, doi:10.1016/j.renene.2014.11.034, 2015.

Sanil Kumar, V., Dubhashi, K. K., Nair, T. M. B., and Singh, J.: Wave power potential at few shallow water locations around Indian coast, Curr. Sci. India, 104, 1219-1224, 2013.

Shanas, P. R. and Sanil Kumar, V.: Temporal variations in the wind and wave climate at a location in the eastern Arabian Sea based on ERA-Interim reanalysis data, Nat. Hazards Earth Syst. Sci., 14, 1371-1381, doi:10.5194/nhess-14-1371-2014, 2014.

Sierra, J. P., González-Marco, D., Sospedra, J., Gironella, X., Mösso, C., and Sánchez-Arcilla, A.: Wave energy resource assessment in Lanzarote (Spain), Renew. Energ., 55, 480-489, 2013.

Soares, C. G., Bento, A. R., Gonçalves, M., Silva, D., and Martinho, P.: Numerical evaluation of the wave energy resource along the Atlantic European coast, Comput. Geosci., 71, 37-49, 2014.

Stopa, J. E., Cheung, K. F., and Chen, Y. L.: Assessment of wave energy resources in Hawaii, Renew. Energ., 36, 554-567, 2011.

URS: Wave power feasibility study report, City and Country of San Francisco, Job No. 28067508, 1-49, 2009. 